\title{
An evaluation of the potential radiative forcing and climatic impact of marine organic aerosols as heterogeneous ice nuclei
}

\author{
Yuxing Yun ${ }^{1,2}$ and Joyce E. Penner ${ }^{1}$ \\ Received 21 May 2013; revised 15 July 2013; accepted 23 July 2013; published 12 August 2013.
}

[1] Observational evidence demonstrates that marine organic aerosols (MOA) are able to act as ice nuclei. MOA explains a substantial portion of the submicron marine aerosol, so that they have the potential to effectively influence marine cloud microphysics and cloud radiative forcing. This study provides the first evaluation of the radiative forcing and climatic impact of marine organic aerosols as ice nuclei on a global scale. MOA is implemented into a coupled aerosol and general circulation model. It is found that MOA contributes to more ice formation than dust or black carbon/ organic matter in mixed-phase clouds. They also have a significant impact on the ice water path in the Southern Hemisphere and therefore could be an important missing source of ice nuclei in current models. The addition of MOA as natural heterogeneous ice nuclei reduces the magnitude of the total top-of-atmosphere anthropogenic aerosol forcing by as much as $0.3 \mathrm{~W} / \mathrm{m}^{2}$. Citation: Yun, Y., and J. E. Penner (2013), An evaluation of the potential radiative forcing and climatic impact of marine organic aerosols as heterogeneous ice nuclei, Geophys. Res. Lett., 40, 4121-4126, doi:10.1002/grl.50794.

\section{Introduction}

[2] Ocean covers about $70 \%$ of the Earth's surface and marine aerosols are thus an important component of the global aerosol field. Recent measurements have found that organic aerosols contribute as much as $63 \%$ of the submicron aerosol mass during phytoplankton blooms [O'Dowd et al., 2004; Cavalli et al., 2004]. Marine organic aerosols (MOA) can be of primary or secondary origin. Primary MOAs are directly ejected from the ocean surface through bubble bursting processes and are composed of whole cells or fragments of phytoplankton, polysaccharides, and proteins [Hawkins and Russell, 2010]. Secondary MOAs are produced within the atmosphere from the oxidation of emitted biogenic volatile organic compounds (VOCs) such as isoprene, monoterpenes, and amines [Meskhidze et al., 2011].

[3] Marine organic aerosols have been shown to influence cloud microphysical properties over the remote ocean by acting as cloud condensation nuclei $(\mathrm{CCN})$ in both observation and model studies [O'Dowd et al., 2004; Roelofs, 2008]. The properties of primary MOA are not well known,

\footnotetext{
${ }^{1}$ Department of Atmospheric, Oceanic, and Space Sciences, University of Michigan, Ann Arbor, Michigan, USA.

${ }^{2}$ Now at AOS Program, Princeton University/Geophysical Fluid Dynamics Laboratory, Princeton, New Jersey, USA.

Corresponding author: Y. Yun, AOS Program, Princeton University/ Geophysical Fluid Dynamics Laboratory, 300 Forrestal Road, Princeton, NJ 08544, USA. (Yuxing.Yun@noaa.gov)

(C)2013. American Geophysical Union. All Rights Reserved. 0094-8276/13/10.1002/grl.50794
}

particularly for large organic plume events where dichotomous behavior of low hygroscopicity and high CCN activity is encountered [Ovadnevaite et al., 2011]. During such events, CCN concentrations can exceed 400 per cc and, given their hydrogel properties, are likely to contribute in significant numbers to heterogeneous ice nuclei (IN). However, there are only a few studies of the effects of MOA acting as ice nuclei. Several observational studies report that marine aerosols may act as ice nuclei. Bigg [1973] (B73 hereafter) made long-term measurements of ice nuclei concentrations in the marine boundary layer over Australia and the Antarctic Ocean. He found that the highest ice nuclei concentrations were in the subtropical convergence zone along the 40S parallel, where marine biological activities are strong due to nutrient upwelling. Schnell [1975] and Schnell and Vali [1976] found that seawater which is rich in phytoplankton is a good source of ice nuclei, with some active IN at temperatures as high as $-4^{\circ} \mathrm{C}$. More recently, Knopf et al. [2011] identified the marine phytoplanktonic diatom Thalassiosira pseudonana as efficient ice nuclei in the deposition mode at typical cirrus onset temperatures and in the immersion mode at mixed-phase cloud temperatures. DeMott et al. [2012] measured the ice nucleation activity of laboratory generated sea spray aerosols and found the lowest IN concentrations in samples with high organic aerosol loading, but IN concentrations increased following the addition of bacteria and nutrients after the cells had fed on these nutrients.

[4] Due to the large contribution of MOA to the total marine aerosol number concentration and their ice nucleation properties, they have the potential to effectively influence marine cloud microphysics and cloud radiative forcing. Most previous models do not consider aerosol properties when predicting ice number concentrations. Yun and Penner [2012] found that after switching to an aerosol-dependent ice nucleation parameterization, and adjusting the contact freezing parameterization of Young [1974] to fit the Blanchard [1957] observations, the model under-predicted the ice water path in the Southern Hemisphere (SH) by about $30 \mathrm{~g} / \mathrm{m}^{2}$ near $60 \mathrm{~S}$. The original Young [1974] parameterization was a temperature scaling of the IN concentration measured by the Blanchard [1957] at $-4^{\circ} \mathrm{C}\left(0.2 \mathrm{~cm}^{-3}\right)$. Most models replace this $0.2 \mathrm{~cm}^{-3}$ with aerosol concentrations without applying any restrictions. Yun and Penner [2012] restricted the predicted contact ice nuclei to fit the Blanchard [1957] measurement $\left(0.2 \mathrm{~cm}^{-3}\right)$ for the same condition. This renders the contact ice nuclei to be $0.2 \%$ of the dust number concentration and $0.02 \%$ of black carbon and organic matter (BOC) number concentration at $-4^{\circ} \mathrm{C}$. Part of the reason for the decrease in the ice water path was that only dust, black carbon, and terrestrial organic carbon were ice nuclei in the parameterization, as is also the case in other aerosol-dependent parameterizations [Chen et al., 2008; Khvorostyanov and Curry, 2004; Diehl et al., 2006]. 
Table 1. Sensitivity Simulations

\begin{tabular}{|c|c|}
\hline Simulation & Description \\
\hline No_MOA & No MOA \\
\hline Reference & $\begin{array}{c}\text { Meskhidze et al. [2011] sea-salt emission, } \\
\text { Gantt et al. [2011] MOA fraction }\end{array}$ \\
\hline Sslt_Emis & Sea-salt emission changed to Jaegle et al. [2011] \\
\hline MOA_Frac & MOA fraction changed to modified Vignati et al. [2010] \\
\hline Frz_Less & $\begin{array}{c}\text { Reference case with ice nucleation efficiency of } \\
\text { MOA decreased by a factor of } 10\end{array}$ \\
\hline Frz_More & $\begin{array}{l}\text { Reference case with ice nucleation efficiency of } \\
\text { MOA increased by a factor of } 10\end{array}$ \\
\hline
\end{tabular}

This change resulted in an under-prediction of ice water in the $\mathrm{SH}$, and led to a bias in the present-day cloud radiative forcing. This problem does not seem to be present in other global models that use aerosol-dependent ice nucleation parameterizations [Lohmann et al., 2007; Storelvmo et al., 2011], but these models have not limited contact nucleation in the same manner as we do.

[5] The effects of marine organic aerosols as ice nuclei have not yet been evaluated on a global scale. It is possible that the inclusion of an oceanic source of ice nuclei would allow the IWP in the SH to fit observations when using an aerosol-dependent ice nucleation parameterization. In this study, we implement MOA in a global aerosol transport model. The aerosol model is coupled to a general circulation model and we introduce an ice nucleation parameterization for MOA. An assessment of the possible effects of MOA as heterogeneous ice nuclei in mixed-phase clouds shows that the IWP is in better agreement with observations when ice nucleation by MOA is included.

\section{Methods}

\subsection{Model}

[6] We used the coupled CAM3+ general circulation model with the IMPACT aerosol transport model. The CAM3+ model has been updated from CAM3 to include a double moment cloud microphysics scheme [Wang and Penner, 2010] for cloud liquid and ice. Heterogeneous ice nucleation in mixed-phase clouds is treated using Phillips et al. [2008] and the adjusted Young [1974] parameterization [Yun and Penner, 2012]. The Eidhammer et al. [2010] modification to Phillips et al. [2008] has been incorporated. The IMPACT aerosol transport model considers detailed sulfate chemistry and emission, dry deposition, and wet deposition for all other major aerosols types (organic aerosols, black carbon, dust, and sea salt). The model has also been updated to predict three levels of hygroscopicity for fossil fuel soot and the effects of hygroscopicity on ice nucleation [Yun et al., 2013].

\subsection{Emission of Marine Organic Aerosols}

[7] In this study, the emission of the marine biogenic aerosols was parameterized as a function of the sea-salt emissions. Two methods for the calculating sea-salt emissions and two methods for calculating the mass fraction of marine organics were tested. The first method for calculating sea-salt emissions is the same as that used by Meskhidze et al. [2011] and uses the Martensson et al. [2003] scheme for particles $2.8 \mu \mathrm{m}$ and the Monahan and O'Muircheartaigh [1986] parameterization for sea-salt sizes larger than $2.8 \mu \mathrm{m}$. The second method is that proposed by Jaegle et al. [2011], who added a dependence on the sea surface temperature (SST) to the Gong [2003] parameterization. The mass fraction of sea salt that is associated with organics was parameterized using either the Gantt et al. [2011] parameterization or the modified Vignati et al. [2010] parameterization [Meskhidze et al., 2011], which in turn is based on the scheme originally proposed by O'Dowd et al. [2008]. MOA are predicted for the same four size bins as sea salt, namely, for radii ranging from 0.05 to $0.63 \mu \mathrm{m}, 0.63$ to $1.26 \mu \mathrm{m}, 1.26$ to $2.5 \mu \mathrm{m}$, and 2.5 to $10 \mu \mathrm{m}$. The density of MOA is assumed to be $1 \mathrm{~g} / \mathrm{cm}^{3}$ [Cavalli et al., 2004].

\subsection{Ice Nucleation Efficiency of Marine Organic Aerosols}

[8] We derived the ice nucleation efficiencies of MOA for each size bin using the measurements of B73. Since B73 used the membrane filter technique to measure IN, and since the IN parameterization in $\mathrm{CAM} 3+$ relies on data from the continuous flow diffusion chamber (CFDC) method [Phillips et al., 2008], we did not use the B73 data directly. Instead, we used the ratio of the measured ice nuclei concentrations at different locations together with our model-estimated aerosol concentrations. Schnell and Vali [1976] have calculated the average ice nuclei concentration over Australia and the Antarctic Ocean (40S latitude band) based on B73. At $-15^{\circ} \mathrm{C}$ at water saturation, the ratio of ice nuclei number concentration between the two regions (Australia:40S) was 1:3 [Schnell and Vali, 1976].

[9] We calculated the nucleation efficiency of MOA using the modeled aerosol concentrations together with the Phillips et al. [2008] parameterization by fitting the 1:3 ratio between Australia and $40 \mathrm{~S}$ as summarized in the following equation:

$\left(C_{O, A u} \times F o+C_{M O A, A u} \times F m o a\right) \times 3=C_{O, 40} \times F o+C_{M O A, 40} \times F m o a$

$C_{O}$ is the modeled number concentration for other aerosol types (besides MOA, i.e., dust and BOC) at Australia (Au) and at $40 \mathrm{~S}$ (40). $C_{M O A}$ is the MOA number concentration for the same regions. $F_{O}$ is the frozen fraction of non-MOA aerosol at $-15^{\circ} \mathrm{C}$ at water saturation, as predicted using the Phillips et al. [2008] parameterization. Fmoa is the MOA frozen fraction for the same condition and is the only unknown variable here. We set an upper limit for Fmoa of $100 \%$. Using this equation, we calculated the frozen fraction of $\mathrm{MOA}$ at $-15^{\circ} \mathrm{C}$ at water saturation, to be $3.75 \%$ for the smallest size bin $(0.05-0.63 \mu \mathrm{m})$, and $100 \%$ for all of the larger size bins. These fractions are then used to constrain the Phillips parameterization as applied for all other conditions. The nucleation efficiency is larger for larger size bins due to the dependence of the nucleation efficiency on the aerosol surface area [Phillips et al., 2008]. As a comparison, laboratory measurements by Knopf et al. [2011] showed that at $240 \mathrm{~K}$ and $\mathrm{RH}$ of $95 \%$, about $63 \%$ of aqueous $\mathrm{NaCl}$ droplets containing marine diatoms freeze in $9 \mathrm{~s}$.

Table 2. MOA Annual Emission in Each Size Bin (Tg/yr)

\begin{tabular}{lccc}
\hline Sizes $(\mu \mathrm{m})$ & Reference & Ssit_Emis & MOA_Frac \\
\hline $0.05-0.63$ & 9.56 & 6.31 & 10.87 \\
$0.63-1.26$ & 3.36 & 2.57 & 3.62 \\
$1.26-2.5$ & 6.67 & 8.72 & 8.24 \\
$2.5-10$ & 13.03 & 20.92 & 16.35 \\
Total & 32.61 & 38.51 & 39.08 \\
\hline
\end{tabular}



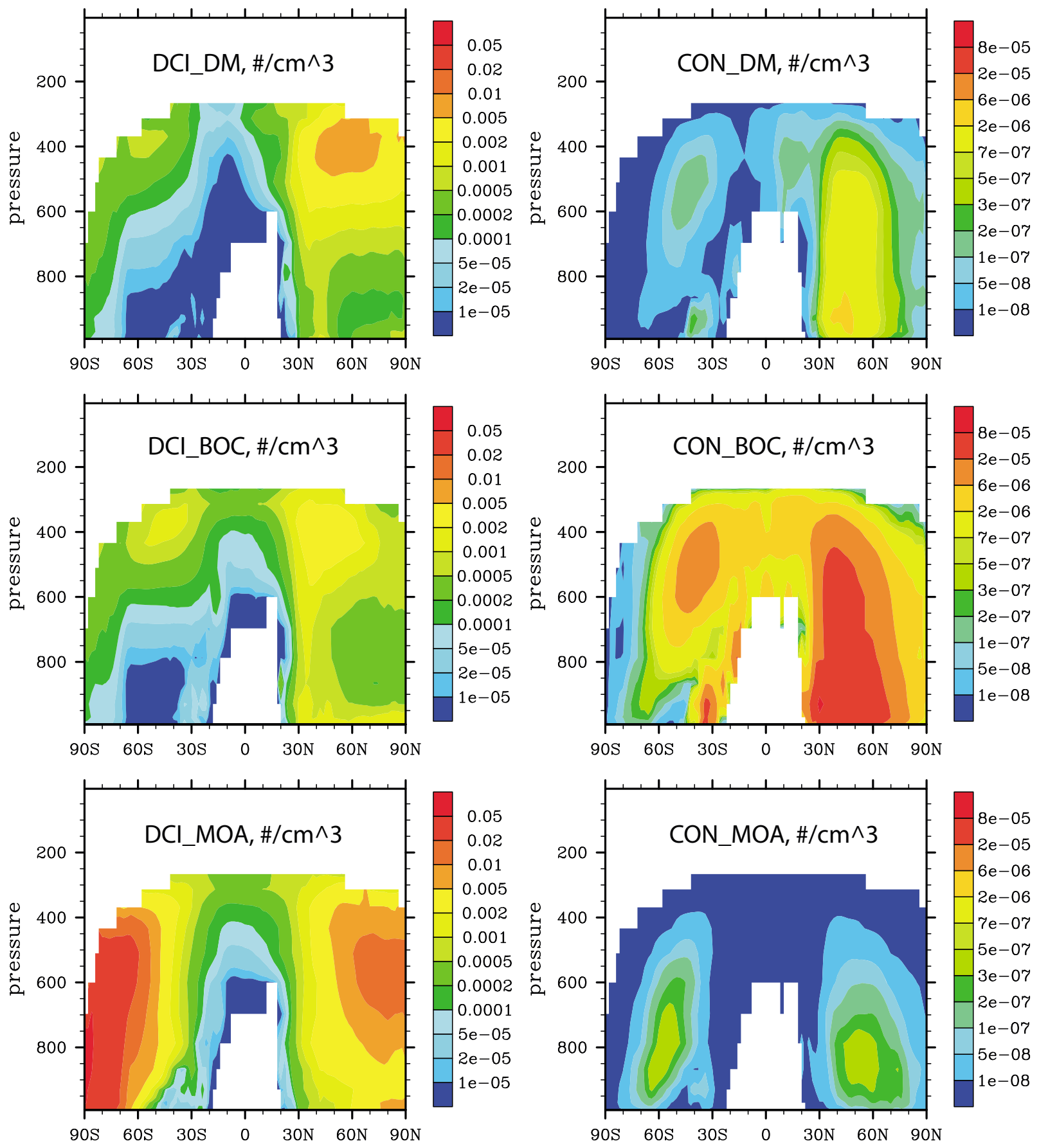

Figure 1. Ice number concentration from dust (DM), black and organic carbon (BOC), and MOA for condensation/immersion freezing (left column), and contact freezing (right column) in the Reference case.

[10] Our parameterization of IN concentrations for MOA differs from that developed by Burrows et al. [2013]. Burrows et al. [2013] parameterized marine biological IN emission at $-15^{\circ} \mathrm{C}$ with sea spray emissions modified by an ocean biological variable (chlorophyll or particulate organic carbon), and a scaling factor, which was calculated as a product of five factors. The value for the scaling factor was chosen so that the IN concentrations agreed as well as possible with the B73 observations. The frozen fraction of marine organic aerosol at $-15^{\circ} \mathrm{C}$ calculated using their method is on the order of $10^{-4}-10^{-5}$ [Burrows, personal communication, 2013] whereas our method predicts a value of $3.75 \%$ for the smallest size bin $(0.05-0.63 \mu \mathrm{m})$, and $100 \%$ for the larger size bins.
[11] The uncertainties in our derived ice nucleation efficiency are associated with the uncertainties in the predicted aerosol number concentration and the predicted ice nucleation efficiency from the Phillips parameterization. The model annual average predicted dust concentration and black carbon concentration is smaller than the observations by Wolff and Cachier [1998] at Halley, Antarctica by about a factor of 2 (see comparison in Wang et al. [2009]). On the other hand, the Phillips et al. [2008] parameterization has been shown to overpredict ice nucleation by dust and soot at warm subzero temperatures. At $-15^{\circ} \mathrm{C}$, the overprediction is about a factor of 10 [Phillips et al., 2013]. The model predicted 


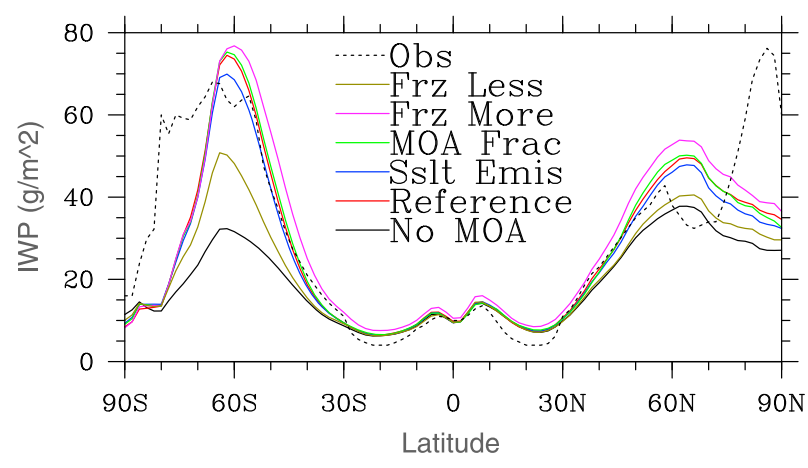

Figure 2. Zonal and annual mean ice water path (IWP) from the six present-day model experiments described in Table 1. Black dotted lines refer to ISCCP data for IWP (http://isccp.giss.nasa.gov/).

marine organic concentrations in Lapina et al. [2011] were shown to be larger than observations by as much as a factor of 6 . Since the submicron MOA emissions rates in Lapina et al. [2011] are close to those predicted by our model (section 3.1), we expect our model to have a similar overprediction in comparison to observations. Taking these various factors into account, the "true" MOA frozen fraction might be different than our derived value by a factor of 1.2. Below, we test the sensitivity of the simulated ice/liquid water path and cloud radiative forcing to the derived MOA ice nucleation efficiency by increasing and decreasing the efficiency by a factor of 10, which covers the range of uncertainty.

[12] MOA is also added as contact ice nuclei with the same efficiency as BOC in the adjusted Young contact freezing treatment. However, contact ice nuclei are not constrained by B73 since the measurement method does not account for contact freezing.

\subsection{Experimental Setup}

[13] A total of six sensitivity simulations were performed which are used to explore changes in the sea-salt emissions inventory, the fraction of sea salt assumed to be MOA, and the ice nucleation efficiency of MOA (see descriptions in Table 1). All simulations are run for 5 years and 4 months. The first 4 months are treated as model spin-up and are excluded from the analysis. Since we are mainly interested in the effect of MOA in mixed phase clouds, MOA was not included in the aerosol direct effect and aerosol indirect effect in warm and cirrus ice clouds.

\section{Results}

\subsection{Marine Organic Aerosol Emission, Burden, and Lifetime}

[14] Table 2 lists the global annual emissions of the MOA aerosols in each size bin predicted from the Reference, Sslt_Emis, and MOA_Frac cases. The emissions of MOA decrease from the first size bin to the second and then increase with larger aerosol size. Compared to the reference case, the Jaegle et al. [2011] sea-salt emission function produces smaller emissions for the first two size bins, but larger emissions for the larger sizes. Larger MOA emissions than the reference case are produced for all size bins using the modified Vignati et al. [2010] MOA fractions. Assuming an OM/OC ratio of 1.4 [Liousse et al., 1996], the submicron $(<1 \mu \mathrm{m})$ MOA emissions for the Reference, Sslt_Emis, and MOA_Frac cases are 8.24, 5.59, and 9.29 TgC/yr, respectively. These are close to the predicted submicron MOA emissions from Lapina et al. [2011] (8.2-8.9 TgC/yr). The emissions of MOA for the Reference case (11.53 Tg/yr) are larger than that predicted by Meskhidze et al. [2011] (9.4 Tg/yr) with the same sea salt and MOA fraction. One possible reason is the larger wind speed between 40 and $60 \mathrm{~S}$ in the CAM3+ model compared to that in CAM5, which was the model used by Meskhidze et al. [2011].

\subsection{Contribution from MOA vs. Other Aerosols to Ice Nucleation}

[15] It is informative to compare the contribution of MOA to ice number concentration with that of other aerosols, to gain some insight into the relative importance of MOA as ice nuclei (Figure 1). For condensation/immersion freezing, the contribution from dust and black and organic carbon (BOC) is larger in the Northern Hemisphere (NH) than the $\mathrm{SH}$. However, the contribution from MOA is larger in the $\mathrm{SH}$, consistent with the MOA emission distribution. For condensation/immersion freezing, MOA is the dominant ice nuclei species. Burrows et al. [2013] also found that marine ice nuclei play a dominant role in determining ice nuclei concentrations over the Southern Ocean.

[16] For contact freezing, the contribution of dust and BOC is also larger in the $\mathrm{NH}$, while that from MOA is comparable in the $\mathrm{NH}$ and $\mathrm{SH}$. BOC dominates contact freezing due to their large number concentration, dust is second, and MOA is last. However, since the ice number formed from condensation/immersion freezing is about three orders of magnitude larger than that formed from contact freezing, the formation of ice particles is dominated by the MOA aerosol.

Table 3. Global Means of Mixed-Phase Cloud Ice Number (mNi), Vertically Integrated Liquid/Ice Water Paths, and Cloud Radiative Forcing

\begin{tabular}{|c|c|c|c|c|c|c|c|}
\hline Simulation & $\mathrm{mNi}\left(10^{10} \mathrm{~m}^{-2}\right)$ & $\operatorname{IWP}\left(\mathrm{g} \mathrm{m}^{-2}\right)$ & $\operatorname{LWP}\left(\mathrm{g} \mathrm{m}^{-2}\right)$ & $\operatorname{SWCF}\left(\mathrm{W} \mathrm{m} \mathrm{m}^{-2}\right)$ & $\mathrm{LWCF}\left(\mathrm{W} \mathrm{\textrm {m } ^ { - 2 } )}\right.$ & $\Delta \mathrm{NCF}\left(\mathrm{W} \mathrm{m}{ }^{-2}\right)$ & $\Delta \operatorname{NFT}\left(\mathrm{W} \mathrm{m}^{-2}\right)$ \\
\hline No_MOA & 0.00097 & 16.13 & 94.85 & -55.34 & 28.82 & -0.36 & -2.82 \\
\hline Reference & 0.00230 & 21.83 & 74.11 & -50.63 & 25.92 & -0.03 & -2.52 \\
\hline Sslt_Emis & 0.00175 & 20.99 & 77.26 & -51.56 & 26.25 & & \\
\hline MOA_Frac & 0.00327 & 22.10 & 72.23 & -49.99 & 25.76 & & \\
\hline Frz_More & 0.00909 & 24.53 & 59.88 & -45.39 & 24.41 & & \\
\hline Frz_Less & 0.00107 & 17.96 & 87.78 & -54.19 & 27.84 & & \\
\hline $\mathrm{Obs}$ & & 21.2 & 50 to 87 & -47 to -54 & 22 to 30 & & \\
\hline
\end{tabular}

$\triangle \mathrm{NCF}$ is the change of net cloud forcing from pre-industrial to present-day. $\triangle \mathrm{NFT}$ is the net forcing change at TOA. The observational data used are described in Yun and Penner [2012]. 


\subsection{Cloud Liquid/Ice Water Field and Radiative Forcing}

[17] The ice water path (IWP) of all six simulations is compared to ISCCP observations in Figure 2. As noted in the introduction, the No_MOA case without MOA as heterogeneous ice nuclei under-predicts IWP between 40 and 70S. In all the cases where MOA are included as heterogeneous ice nuclei, the IWP in this region increases and compares better with observations. IWP is most sensitive to the decrease of the ice nucleation efficiency of MOA by a factor of 10 .

[18] The global mean IWP increases from $16.13 \mathrm{~g} / \mathrm{m}^{2}$ in the No MOA case to $21.83 \mathrm{~g} / \mathrm{m}^{2}$ in the Reference case, which is in better agreement with the observed value of $21.2 \mathrm{~g} / \mathrm{m}^{2}$ (Table 3). The global mean liquid water path (LWP) also decreases due to the Bergeron-Findeisen process by $20.74 \mathrm{~g} / \mathrm{m}^{2}$, which brings it to within the range of satellite observations. The absolute value of the net cloud forcing (NCF) decreases by $1.81 \mathrm{~W} / \mathrm{m}^{2}$.

[19] The simulations with MOA as a heterogeneous ice nuclei using the standard derived ice nucleation efficiency (cases Reference, Sslt_Emis, and MOA_Frac) compare better to satellite observations of IWP, LWP, short-wave cloud forcing (SWCF), and long-wave cloud forcing (LWCF) than do the simulations with MOA ice nucleation efficiencies increased or decreased by a factor of 10 (Frz_More and Frz_Less). The latter either overestimate or underestimate these variables compared to satellite observations. Generally, varying the ice nucleation efficiency of MOA produces larger changes in IWP than changing the MOA emission rates as a result of using different parameterizations. Experimental studies that better quantify the ice nucleation efficiencies of MOA aerosols are needed for more accurate estimates of their effect on IWP.

\section{Discussion}

[20] This study is the first assessment of the radiative forcing and climatic impact of marine organic aerosols as a result of their action as heterogeneous ice nuclei in mixed-phase clouds. MOA is found to contribute more to ice formation than dust or BOC in mixed-phase clouds. As ice nuclei, marine organic aerosols have significant impact on the IWP in the Southern Hemisphere. The comparison of IWP to ISCCP observations is improved significantly with the addition of MOA as heterogeneous ice nuclei in mixedphase clouds. However, global models up to now do not have any considerations of MOA as heterogeneous ice nuclei. Our study points out that this could be an important missing ice nuclei source for the SH. To examine the effect of including MOA as heterogeneous ice nuclei to the anthropogenic aerosol forcing, we also conducted preindustrial runs for the No MOA case and the Reference case. We note that the addition of MOA reduces the magnitude of anthropogenic aerosol net cloud forcing including changes in all cloud types from -0.36 to $-0.03 \mathrm{~W} / \mathrm{m}^{2}$, i.e., by $0.33 \mathrm{~W} / \mathrm{m}^{2}$ (Table 3 ). The anthropogenic aerosol top-of-atmosphere (TOA) net forcing is reduced from $-2.82 \mathrm{~W} / \mathrm{m}^{2}$ to $-2.52 \mathrm{~W} / \mathrm{m}^{2}$. Since our results indicate that the ice nucleation efficiency of MOA could be fairly large, future laboratory studies and field campaigns that focus on the ice nucleation properties of MOA are needed for a more accurate estimate of their effect.
[21] Acknowledgments. The authors would like to thank Xianglei Huang, Derek Posselt, Gregory Dick, Allison Steiner, Mark Flanner, and Xiuhong Chen at University of Michigan for useful comments.

[22] The Editor thanks two anonymous reviewers for their assistance evaluating this manuscript.

\section{References}

Bigg, E. K. (1973), Ice nucleus concentrations in remote areas, J. Atmos Sci., 30(6), 1153-1157.

Blanchard, D. C. (1957), The supercooling, freezing and melting of giant waterdrops at terminal velocity in air, in Artificial Simulation of Rain, pp. 233-249, Pergamon Press, London.

Burrows, S. M., C. Hoose, U. Pöschl, and M. G. Lawrence (2013), Ice nuclei in marine air: bioparticles or dust?, Atmos. Chem. Phys., 13, 245-267, doi:10.5194/acp-13-245-2013.

Cavalli, F., et al. (2004), Advances in characterization of size-resolved organic matter in marine aerosol over the North Atlantic, J. Geophys. Res., 109, D24215, doi:10.1029/2004JD005137.

Chen, J. P., A. Hazra, and Z. Levin (2008), Parameterizing ice nucleation rates using contact angle and activation energy derived from laboratory data, Atmos. Chem. Phys., 8(24), 7431-7449.

DeMott, P., et al. (2012), Ice nuclei production from sea spray, paper presented at 31st Conference on American Association on Aerosol Research, Am. Assoc. Aer. Res., Minneapolis, Min.

Diehl, K., M. Simmel, and S. Wurzler (2006), Numerical sensitivity studies on the impact of aerosol properties and drop freezing modes on the glaciation, microphysics, and dynamics of clouds, J. Geophys. Res., 111, D07202, doi:10.1029/2005JD005884

Eidhammer, T., et al. (2010), Ice initiation by aerosol particles: Measured and predicted ice nuclei concentrations versus measured ice crystal concentrations in an orographic wave cloud, J. Atmos. Sci., 67, 2417-2436, doi:10.1175/2010JAS3266.1.

Gantt, B., N. Meskhidze, M. C. Facchini, M. Rinaldi, D. Ceburnis, and C. D. O'Dowd (2011), Wind speed dependent size-resolved parameterization for the organic mass fraction of sea spray aerosol, Atmos. Chem. Phys., 11(16), 8777-8790.

Gong, S. L. (2003), A parameterization of sea-salt aerosol source function for sub- and super-micron particles, Global Biogeochem. Cycles, 17(4), 1097, doi:10.1029/2003GB002079.

Hawkins, L. N., and L. Russell (2010), Polysaccharides, Proteins, and Phytoplankton Fragments: Four Chemically Distinct Types of Marine Primary Organic Aerosol Classified by Single Particle Spectromicroscopy, Adv. Meteorol., doi:10.1155/2010/612132.

Jaegle, L., P. K. Quinn, T. S. Bates, B. Alexander, and J. T. Lin (2011), Global distribution of sea salt aerosols: new constraints from in situ and remote sensing observations, Atmos. Chem. Phys., 11(7), 3137-3157.

Khvorostyanov, V. I., and J. A. Curry (2004), The theory of ice nucleation by heterogeneous freezing of deliquescent mixed CCN, Part I: Critical radius, energy, and nucleation rate, J. Atmos. Sci., 61(22), 2676-2691.

Knopf, D. A., P. A. Alpert, B. Wang, and J. Y. Aller (2011), Stimulation of ice nucleation by marine diatoms, Nat. Geosci., 4(2), 88-90.

Lapina, K., et al. (2011), Investigating organic aerosol loading in the remote marine environment, Atmos. Chem. Phys., 11(17), 8847-8860.

Liousse, C., J. E. Penner, C. Chuang, J. J. Walton, H. Eddleman, and H. Cachier (1996), A global three-dimensional model study of carbonaceous aerosols, J. Geophys. Res., 101(D14), 19,411-19,432, doi:10.1029/95jd03426.

Lohmann, U., P. Stier, C. Hoose, S. Ferrachat, S. Kloster, E. Roeckner, and J. Zhang (2007), Cloud microphysics and aerosol indirect effects in the global climate model ECHAM5-HAM, Atmos. Chem. Phys., 7, 3425-3446.

Martensson, E. M., E. D. Nilsson, G. de Leeuw, L. H. Cohen, and H. C. Hansson (2003), Laboratory simulations and parameterization of the primary marine aerosol production, J. Geophys. Res., 108(D9), 4297, doi:10.1029/2002JD002263.

Meskhidze, N., J. Xu, B. Gantt, Y. Zhang, A. Nenes, S. J. Ghan, X. Liu, R. Easter, and R. Zaveri (2011), Global distribution and climate forcing of marine organic aerosol: 1. Model improvements and evaluation, Atmos. Chem. Phys., 11(22), 11,689-11,705.

Monahan, E. C., and I. G. O'Muircheartaigh (1986), Whitecaps and the passive remote sensing of the ocean surface, Int. J. Remote Sens., 7(5), 627-642.

O'Dowd, C. D., M. C. Facchini, F. Cavalli, D. Ceburnis, M. Mircea, S. Decesari, S. Fuzzi, Y. J. Yoon, and J. P. Putaud (2004), Biogenically driven organic contribution to marine aerosol, Nature, 431(7009), 676-680.

O’Dowd, C. D., B. Langmann, S. Varghese, C. Scannell, D. Ceburnis, and M. C. Facchini (2008), A Combined Organic-inorganic Sea-Spray Source Function, Geophys. Res. Lett., 35, L01801, doi:10.1029/2007GL030331.

Ovadnevaite, J., D. Ceburnis, J. Bialek, C. Monahan, G. Martucci, M. Rinaldi, M. C. Facchini, H. Berresheim, D. R. Worsnop, and C. O'Dowd (2011), Primary Marine Organic Aerosol: A Dichotomy of Low Hygroscopicity and High CCN Activity, Geophys. Res. Lett., 38, L21806, doi:10.1029/2011GL048869. 


\section{YUN AND PENNER: MARINE ORGANIC AEROSOLS AS ICE NUCLEI}

Phillips, V. T. J., P. J. DeMott, and C. Andronache (2008), An empirical parameterization of heterogeneous ice nucleation for multiple chemical species of aerosol, J. Atmos. Sci., 65(9), 2757-2783.

Phillips, V. T. J., P. J. Demott, C. Andronache, K. A. Pratt, K. A. Prather, R. Subramanian, and C. Twohy (2013), Improvements to an empirical parameterization of heterogeneous ice nucleation and its comparison with observations, J. Atmos. Sci., 70, 378-409, doi:10.1175/JAS-D-12-080.1.

Roelofs, G. J. (2008), A GCM study of organic matter in marine aerosol and its potential contribution to cloud drop activation, Atmos. Chem. Phys., 8(3), 709-719.

Schnell, R. C. (1975), Ice nuclei produced by laboratory cultured marine phytoplankton, Geophys. Res. Lett., 2(11), 500-502.

Schnell, R. C., and G. Vali (1976), Biogenic ice nuclei .1. terrestrial and marine sources, J. Atmos. Sci., 33(8), 1554-1564.

Storelvmo, T., C. Hoose, and P. Eriksson (2011), Global modeling of mixedphase clouds: The albedo and lifetime effects of aerosols, J. Geophys. Res., 116, D05207, doi:10.1029/2010JD014724.

Vignati, E., M. C. Facchini, M. Rinaldi, C. Scannell, D. Ceburnis, J. Sciare, M. Kanakidou, S. Myriokefalitakis, F. Dentener, and C. D. O’Dowd
(2010), Global scale emission and distribution of sea-spray aerosol: Sea-salt and organic enrichment, Atmos. Environ., 44(5), 670-677.

Wang, M., and J. E. Penner (2010), Cirrus clouds in a global climate model with a statistical cirrus cloud scheme, Atmos. Chem. Phys., 10(12), 5449-5474.

Wang, M. H., J. E. Penner, and X. H. Liu (2009), Coupled IMPACT aerosol and NCAR CAM3 model: Evaluation of predicted aerosol number and size distribution, J. Geophys. Res, 114, D06302, doi:10.1029/2008JD010459.

Wolff, E. W., and H. Cachier (1998), Concentrations and seasonal cycle of black carbon in aerosol at a coastal Antarctic station, J. Geophys. Res., 103(D9), doi:10.1029/97jd01363.

Young, K. C. (1974), Numerical simulation of wintertime, orographic precipitation .1. description of model microphysics and numerical technique, J. Atmos. Sci., 31(7), 1735-1748.

Yun, Y., and J. E. Penner (2012), Global model comparison of heterogeneous ice nucleation parameterizations in mixed phase clouds, J. Geophys. Res. 117, D07203, doi:10.1029/2011JD016506.

Yun, Y., J. E. Penner, and O. Popovicheva (2013), The effects of hygroscopicity on ice nucleation of fossil fuel combustion aerosols in mixed-phase clouds, Atmos. Chem. Phys., 13, 4339-4348, doi:10.5194/acp-13-4339-2013. 